\title{
ОБРАЗ БЕДНОСТИ, ОТРАЖЕННЫЙ ВО ФРАЗЕОЛОГИЗМАХ И ПОСЛОВИЦАХ, СОДЕРЖАЩИХ НАЗВАНИЯ ОДЕЖДЫ
}

ЭВА МЛЫНАРЧИК

\section{THE IMAGE OF POVERTY ILLUSTRATED IN PHRASEOLOGICAL UNITS AND PROVERBS CONTAINING NAMES OF CLOTHING}

ABSTRACT The subject of this paper are old and contemporary phraseological and paremiological units which contain the image of insufficient clothing as one of the indicators of poverty. Research material, collected on the basis of phraseological and paremiological dictionaries, has become essential for recreating various elements of the linguistic image of the world: old realities, convictions and judgements preserved in fixed word combinations.

KEY WORDS paremiology, phraseology, linguistic image of the world, poverty, clothing CONTACT Педагогический университет им. Комиссии Народного образования Краков, Институт польской бьлологии; ewa.mlynarczyk@up.krakow.pl 
Предметом моего научного исследования стали петрифицированные словосочетания (фразеологизмы и пословицы), являющиеся свидетельством противостояния обычного человека материальному неблагополучию в разных областях повседневной жизни (Młynarczyk 2015a, 2015b, 2015c, 2016a, 2020). Этот аспект действительности нашел широкое отображение в польской фразеологии и паремиологии (Marmuszewski 1998, 2003; Rak 2015, Wojciechowska 2012), ведь бедность была постоянным спутником многих наших предков, в чем можно убедиться при чтении исторических исследований (см. напр. Skąpska 2003, Sztetyłła 1992, Tarkowska 2000) или воспоминаний людей, выросших в тяжелых материальных условиях.

В настоящей статье будут детально рассмотрены фразеологические и паремические единицы (далее в тексте ФЕ), иллюстрирующие недостатки в одежде, ${ }^{1}$ служащей удовлетворению одной из основных потребностей человека - защиты тела от холода и возможных наружных повреждений. В подборе одежды и ее виде существенны также традиционный и эстетический аспекты.

Исследовательским материалом являются клишированные тексты (пословицы) и мультивербальные единицы разной степени закрепленности в польском языке, которые в соответствии с классификацией Войцеха Хлебды я называю фраземами, формациями словосочетаний, исполняющими - независимо от своих структуральных и семантических черт - условие повторяемости «в данной ситуации и для определения данной связки смыслов» (Chlebda 1993: 3282). Фраземы, анализируемые в данной статье, были собраны из фразео- и паремиологических словарей: Новой книги польских пословиц и поговорок (далее НКП³), Фразеологического словаря польского языка Станислава Скорупки (СФЙП) [Słownik frazeologiczny języka polskiego Stanisława Skorupki (SFJP)], Большого фразеологического словаря ПНИ с пословицами Анны Клошинской, Эльжбеты Соболь и Анны Станкевич (ФСсП) [Wielki słownik frazeologiczny PWN z przysłowiami Anny Kłosińskiej, Elżbiety Sobol i Anny Stankiewicz (SFzP)] и словарей польского языка - Словаря польского языка под редакцией Витольда Дорошевского (СПЯД) [Słownikjęzyka polskiego pod redakcją Witolda Doroszewskiego (SJPD)], Большого словаря польского языка Польской Академии Наук (БСПЯ) [Wielki słownik języka polskiego Polskiej Akademii Nauk (WSJP)]. ${ }^{4}$

Рассматриваемые фраземы служат для воспроизведения составляющих языкового образа мира, понимаемого, согласно Ежи Бартминского, «как заключенную в языке интер-

1 Фразеологические и паремические единицы, отображающие недостаток питания сельского населения, являются предметом отдельного исследования (Młynarczyk 2016a).

2 Согласно В. Хлебде «под фраземой понимается относительно постоянная языковая форма, явившаяся в данной ситуации - независимо от своих структуральных и семантических черт - общепринятым (нередко единственным) способом выражения данного смыслового потенциала» (Chlebda 1993: 328).

3 Расшифровка сокращений вместе с библиографическим описанием находится в конце статьи. В многотомных публикациях (NKP і SFJP) даю детальную локализацию, обозначая римской цифрой том, арабской - страницу (например: NKP II 374). В случае однотомной публикации (SFzP) - даю либо исключительно электронную версию (SJPD, SWJP, WSJP), или ограничиваю локализацию до сокращенного названия словаря.

4 Было бы интересно провести сравнительное исследование пословиц из разных языков. Большой сборник славянских пословиц подготовлен Кафедрой Славистики Санкт-Петербургского Университета (Баловски 2019). 
претацию действительности, которую можно воспринять в виде суждений о мире» (Bartmiński 2006: 76).

Среди собранных единиц преобладают такие, компонентами которых являются названия конкретных предметов одежды. Это, прежде всего, koszula, в прежнем значении - «предмет белья, покрывающий плечи и туловище, который обычно носили непосредственно на теле" (SJPD), ${ }^{5}$ сохранившийся в применяемой до ныне фразе bliższa koszula ciału (niż sukmana / suknia) - „человека интересует только то, что его непосредственно касается». Эта фразема, известная и в краткой, и в более длинной форме, выразительно показывает, что рубаха расценивалась как очень важная часть одежды, самая близкая человеку, поскольку она носится непосредственно на теле и является необходимой - в отличие от остальных элементов одежды. Зафиксированное в SJPD выражение śmiertelna koszula - «рубаха, одеваемая на покойников и приговоренных к смерти» - является свидетельством того, что эта часть гардероба в последние моменты жизни была единственным предметом одежды, покрывавшим тело человека. Недостаточное количество белья было выразительным проявлением бедности, отсюда пословицы с выражениями јеdna / ostatnia koszula, формирующими образ предельной нищеты: zostać w jednej koszuli; zostać / wrócić w jednej / ostatniej koszuli (NKP I 152, WSJP). Некоторые фразеологизмы закрепили оценку низкого материального статуса женщины, выходящей замуж без приданого wziąć żonę w jednej koszuli - «жениться на девице без приданого» (SJPD); «кто-то женился на малоимущей» (WSJP). Иную точку зрения на материальные аспекты замужества дает поговорка choć w jednej koszuli (NKP I 152), применяемая по отношению к женщинам (или ими самими), которые, невзирая на низкий материальный статус мужчины, решаются на брак с ним - Wyjdę za mąż, choćby on był w jednej koszuli (NKP I 152).

Единицы с выражением do (ostatniej) koszuli означают «полностью, до конца, целиком (обеднеть, потерять всё)», говорят о жизненных ситуациях, в результате которых можно существенно обнищать - zgrać się do koszuli; prawować się do ostatniej koszuli; oddać komuś, przepić, sprzedać ostatnią koszulę (SFJP I 349); Do trybunału wchodzisz w kontuszu, w żupanie, a przy wyjściu zaledwie koszula zostanie (NKP III: 538). Потеря материальных благ может быть обусловлена действиями другого человека, на что указывает фразеологизм с каузативным аспектом obedrzeć kogo do koszuli (SFJP I 349) - «способствовать (намеренно) чьему-то полному обнищанию».

Другой частью гардероба, недостаток либо порча которой воспринималась как признак нищеты, являются штаны, в просторечии называвшиеся portkami либо gaciami (лексема gacie имеет также значение «часть мужской одежды, которую носят под штанами»), в прежних реалиях соотносившиеся исключительно с мужчинами. Оборот chodzić / zostać bez portek (NKP i WSJP) используется в смысле «обанкротиться, опуститься» (NKP II 1021), «не иметь денег» (WSJP). В SFJP существует оборот nie mieć całych portek - «не иметь, во что одеться, быть бедным» (SFJP I 723). Фразеологические единицы с выражением ostatnie portki / gacie / spodnie так же, как в приведенной выше группе (ostatnia koszula), описывают

5 В настоящеепвремя основным значением лексемы koszula является «часть одежды, покрывающая туловище и руки, расстегивающаяся спереди, которую надевают на голое тело либо майку, из тонкого материала, носят ее главным образом мужчинами» (WSJP); прежнее значение сохранилось в словосочетаниях koszula nocna, koszulka niemowlęca. 
бедность: wyjść / wynieść się wjednych portkach; trafić gdzieś wjednych portkach / gaciach / spodniach; puścić / wypuścić / zostawić kogoś w jednych portkach / gaciach / spodniach - «ocmambcr лuбo ocmaвить кого-то без денег и иных материальных средств» (WSJP). Меняющиеся предметы одежды в цитируемых оборотах указывают на то, что недостаток белья (не только рубахи) также воспринимался как признак нищеты - wyjść / wynieść się / trafić gdzieś, puścić / wypuścić / zostawić kogoś w jednych majtkach (WSJP); puścić kogoś w skarpetkach / zostać w skarpetkach «yтратить состояние» (WSJP).

Иной речевой оборот - zaciskać pasa, иллюстрирующий необходимость приспособления гардероба к изменяющейся внешности, используется в ситуации ухудшения материального положения и связанной с этим потребности в экономии. Эта метафора связана с народным восприятием худобы как признака бедности. Подобное суждение стало основанием речевого оборота portki na nim ledwie wiszą (NKP II 1021) - «он худой (причиной чего, согласно прежним представлениям, может быть отсутствие еды)».

Следующим элементом гардероба, вид или отсутствие которого свидетельствовал о нищете, является обувь. Это иллюстрируют обороты chodzić bez butów - «ходить босиком» и świecić gołymi / bosymi piętami «ходить босиком или в порванных сапогах» (SFzP); świecić bosymi / gołymi / nagimi piętami (SFJP I 678). Другие единицы сохранили образ изношенной обуви, которая может быть свидетельством материальных трудностей владельца (или его неряшливости): But dziurawy, kupiec głupi, koń bez nóg, sługa niewierny - to do diabła (NKP I 216); Filozof, bo mu palce z butów wyłażą (NKP I 567); Buty jeść / pić wołają (NKP I 216) - «o6 изношенных сапогах, у которых отваливается подошва».

Некоторые паремии напоминают, что покупка сапог была связана с серьезными денежными расходами, на которые не каждый был способен: [Nie] Ni ma na buty, ledwie na przyszycie (NKP I 218), где przyszycie, иначе przyszwa - это «часть башмака, покрывающая стопу и пришитая к подошве, в сапогах с голенищем - и к голенищу» (SJPD); Stać go na buty, nie stać na cholewy (NKP I 219). Сапоги с голенищами, изготовление которых было дорогостоящим по причине большого количества используемой кожи, носили исключительно зажиточные люди. Разницу в стоимости различных типов обуви иллюстрирует пословица Pańska cholewa więcej znaczy niż chłopskie buty (NKP II 799). Эти реалии легли в основу пословицы Znać / poznać pana po cholewach ${ }^{6}$ - «о статусе человека свидетельствует его образ жизни и внешний вид» (SFzP 39), напоминающие о том факте, что самые дорогие сапоги шили из дорогого материала - сафьяна желтого и красного цвета (Olszewski 1984: 232).

Высокая стоимость кожаной обуви была причиной того, что бедные люди справлялись с задачей по-иному - мастерили обувь самостоятельно из материалов, доступных бесплатно - дерева либо лыка7 , о чем напоминают паремии Kogo nie stać na buty, niech w chodakach chodzi (NKP I 218); Chłop wchodził na lipę boso, a schodził obuty (Skuza 2006: 97). Обувь

6 Я. Кжыжановский считал это словосочетание насмешливым по отношению к мелкой шляхте, создающей видимость богатства путем пришивания к новому черному (дешевому) верху цветных (дорогих и издалека заметных) голенищ со старых сапог (Krzyżanowski 1960: 266). В настоящее время эта пословица уже не имеет насмешливого подтекста (Młynarczyk 2012).

7 Łyko - „мягкий, слегка влажный, мясистый слой дерева либо ветви кустарника, находящийся под корой, переносящий в растении воду и органические вещества" (SWJP). Из лыка изготавливались также иные предметы повседневного быта - веревки, корзины, бичи, сита (Skuza 2006). O peчевом образе лыка в польской паремиографии см. Е. Młynarczyk (2015a). 
домашнего изготовления носила разные названия в зависимости от региона - kurpie , $^{8}$ kurpiele, łapcie, chodaki, postoły (SJPD). Некоторые из перечисленных названий стали компонентами пословиц, иллюстрирующих разнообразные аспекты тяжелой материальной действительности: Kto dobrze korpie wyplata, to mu starco na trzy lata (NKP II 258); Przez («без») nauki i łapciów nie uplecie (NKP II 580); Gdy nam zabraknie tyka na chodaki, będziem robić przetaki (NKP II 355).

Низкая цена такой обуви и ее недолговечность, отображенные в пословице Kto chodzi na łykach, musi je drzeć (NKP II 355), ${ }^{9}$ были основанием презрительной оценки, выраженной оборотом trzymać jako o starych kurpiach (NKP II 258) - «игнорирование», ироническое отношение к тем, кто ее носит, в особенности к некоторым представителям польской шляхты: Szlachcic oszmiański: jedna noga $w$ bucie, druga $w$ łapciu (NKP II 754); Jedna noga $w$ bucie, druga w postole (NKP I 218) - «о мелкой шляхте, делающей господский вид»; Z kordem [«мечём»] a boso (NKP I 137) - «о неимущей «застеночной〉 шляхте» и szlachcic chodaczkowy - «неимущий шляхтич, шляхтич на загроде, загоновый шляхтич» (SW I 288). В основе процитированных ФЕ лежит убеждение в том, что обувь была показателем материального положения, с которым в реалиях того времени соотносилось общественное положение. Подобный смысл несут единицы со значением «видимость богатства, прикидываться кем-то, имеющим более высокое общественное положение»-W butach idzie, a boso go znać (NKP I 219); Kwiatki w oknach, a dzieci bez butów (NKP I 218).

Одна из пословиц Kto na cudze buty czeka, musi długo boso chodzić (NKP I 218) говорит о том, как люди находили выход из ситуации, когда обуви не хватало. В беднейших домохозяйствах младший член семейства должен был дожидаться, пока его старшие братья «вырастут» из сапог. Из воспоминаний также известны ситуации, когда братья должны были делить одну пару сапог, в особенности зимой и в официальных случаях, например при посещении костела или школы.

Забота об обуви, дорогом элементе одежды, который быстро изнашивается, упоминается в оборотах, описывающих необходимость посещения множества мест, например, официальных учреждений: Buty zedrzeć za czym / Buty drzeć na próżno (NKP I 217).

Порче подвергалась не только обувь, но и другие части гардероба. Эти недостатки, которые часто замечали окружающие, стали основой метафорической образности во ФЕ: dziurami świecić (NKP I 547); świecić cerami / łatami / dziurami - «носить рваную одежду» (SFzP); Bywa, że pod sajetą ${ }^{10}$ koszula porwana (NKP I 152).

Трудности в обеспечении себя и семьи новой одеждой вынуждали людей к поискам менее дорогостоящих решений - различным формам починки изношенных частей гардероба, таких, как латание, штопка, подшивание (сапог) и т.п. ${ }^{11}$ Такие условия

8 Лексема kurpie - «плетенная из лыка обувь» подверглась онимизации - Китріе это название (изначально скорее прозвище) жителей густых лесов над Нарвой, а также название одного из регионов Мазовша (Malec 1998: 184).

9 В этой пословице глагол drzeć можно прочесть двояко - «ободрать с чего-либо (лыко с дерева)» и «стирать, изнашивать (сапоги)».

10 Sajeta - «изысканное платье из тонкого итальянского сукна, саи» (NKP IV 239).

11 Группа фразем, создающих образ экономного ведения домашнего хозяйства, была более детально проанализирована в другом месте (Młynarczyk 2020). 
повседневной жизни стали основой метафорического образования множества фразеологических единиц, по большей части с глаголом łata либо с глаголом łatać, получившим переносное значение «покрывать расходы, справляться с финансовыми трудностями», например łatać budżet; dziury łatać / zatykać (NKP I 547) - «удовлетворить самые неотложные потребности»; Jak tako, połatawszy (NKP II 337) - «совершить поверхностные изменения»; Dziury dziurą nie przykryje / nie załata (NKP I 547) - «попытка справиться с проблемами путем создания новых, например, оплачивать старые долги за счет новых»; Tu urwie, tu nadstawi I załata (NKP III 103) - «то же» (то же значение выражает паремия Wykupił koszule, a suknia zastawił NKP I 154). Народная мудрость подсказывает, что масштабы починок должны соответствовать масштабам утрат: Jaka dziura, taka łata (NKP I 547).

Некоторые ФЕ с глаголом łatać или существительным Ұata закрепили образ починенной таким путем одежды; часть из них содержит негативную, пренебрежительную оценку как самой одежды, так и людей, носящих латаные вещи: Łata na łacie (SFJP I 405); Łatane rzeczy kata warte (NKP II 338); Chodzić w tatach (SFJP I 405) - «носить очень изношенную, залатанную одежду»; Suknia łatana, buty dziurawe, koń hetka niedobrze świadczą (NKP III 350); Jeden bogaty, na drugim łaty (NKP I 127). Наиболее известным в настоящее время фразеологизмом из этого ряда является оборот przypiąć/ przyczepić komu latkę (SFJP I 405) - «со злым умыслом приписать кому-либо некую негативную черту, особенность, кого-то уколоть, оговорить», напоминающий, что заплата является элементом, выделяющимся на фоне всего костюма. Происхождение этого фразеологизма разъясняет А. Пайджинская (подчеркивая вместе с тем, что мотивация этой фразеологической единицы неясна):

Заплата выделяет вещь, а зачастую вместе с ней и ее владельца. Сильно поношенная, залатанная одежда говорит о бедности или скупости носящего ее человека. Заплаты издавна используются для особого обозначения людей и их осмеяния (вспомним характерные наряды шутов либо клоунов). Таким образом, заплаты на одежде какого-либо человека имеют влияние на формирование мнения о нем, являются значимым элементом, и обычно значимым негативно. (Pajdzińska 2006: 64).

Данная интерпретация имеет отношение также к другим фразеологическим единицам с компонентами łata, łatać. Иронический оттенок имеют ФЕ, содержащие образ людей, наряд которых (а иногда и поведение) исполнен противоречий: Na szyi krawaty, a w koszuli same taty (NKP II 194); Bogaty, a na spodniach łaty (NKP I 125); W kiesieni dukaty, a na schabach («на спине») smaty (NKP I 503); Nowy kabat ze starymi dziurami (NKP II 5).

Другие пословицы являются отображением стереотипных представлений о материальном положении некоторых людей, либо ситуаций, в которых можно оказаться: Z tytu lata, z przodu łata, a pośrodku demokrata (NKP I 419); Kiedy się swatat, czwórką koni latat, a gdy się ożenit, czapka buty łatat (NKP III 356); Kto ma dziatki, temu przydadzą się i łatki (NKP I 530); Gdo w kabácie chodzi, powinien se go tátać (NKP II 5); Filozof-z chleba guziki robi (NKP II 5).

Одна из пословиц отображает убежденность в том, что наряд человека является для него бо́льшим козырем в попытках продвигаться по служебной лестнице и в улаживании чего-либо, чем моральная позиция Człowiek z suknią wytartą daleko nie zajdzie, a człowiek $z$ wytartym czołem prawie wszędzie (NKP I 380). 
Часть подобранных $Ф Е$ выражает положительную оценку латаной одежды, противопоставляя ее вещам грязным, изношенным либо чужим - краденым, одолженным или выклянченным как подаяние: Lepse taty jak smaty (NKP I 337); Lepsza łata niż dziura (NKP II 337); Milsza własna łata niż wyżebrana szata (NKP II 337); Nie wstydzi łata, wstydzi brud (NKP II 337); Lepiej swoje łatać niż cudze chwalić (NKP II 337); Choć łatany, byle nie chwytany (NKP II 337) - «лучше носить одежду латаную, но свою, чем новую, но краденную»; Lepsze łatane niż pożyczane (NKP II 337); Lepiej swoje tatać, niźli cudze chwalić (NKP III 360); Lepsza suknia łatana niż chwytana («краденная») (NKP III 349).

Некоторые паремии отображают суждение, что починенные вещи очень долговечны: Dłużej łatanego niż nowego (NKP II 338); Łatana suknia najtrwalsza (NKP III 349). Другие единицы раскрывают положительную оценку людей, чинивших одежду, поскольку это свидетельствовало об их экономном образе жизни, позволяющим поддерживать материальное положение семьи на должном уровне: Kto się łata i oszczędza, nie zajrzy mu w oczy nędza (NKP II 753); Kto podpiera, grosze zbiera (NKP II 986); Za łatami są pieniądze (NKP II 337).

\section{$1 /$ выводы}

Приведенные речевые единицы представляют собой иллюстрацию народного мировосприятия, характерной чертой которого среди прочего является формулирование суждений и убеждений посредством выразительной в своей образности конкретизации, будущей, в когнитивном понимании языка, проявлением воплощенного мышления. Рассмотренные единицы являются подтверждением такого мышления - суждения на тему чьего-либо материального и общественного положения, уровня обеспеченности, недостатка средств существования выражены посредством образа неполного комплекта одежды либо ее плохого состояния. Компонентами ФЕ являются названия конкретных частей наряда, считавшиеся обязательными - koszula, portki (spodnie, gacie), buty. Это гипонимические понятия по отношению к гиперонимам (например, ubranie, odzież), не выступающим в паремиях, что также свидетельствует о конкретном мышлении, далеком от абстрагирования.

Подобранные мультивербизмы показывают материальное неблагополучие в определенном масштабе. Крайнее положение выражают единицы с оборотами do (ostatniej) koszuli; w jednej / ostatniej koszuli; w jednych portkach / gaciach; bez portek / majtek; w skarpetkach. Другие ФЕ подчеркивают заметные для окружающих признаки нищеты - дыры, заплаты (świecić cerami / łatami/ dziurami; łata na łacie; Nowy kabat ze starymi dziurami).

Анализируемые словосочетания иллюстрируют характерную для общественного мировосприятия оценку чьего-либо материального и общественного положения на основании наряда (Роznać pana po cholewach; Łykiem człowieka nie mierz), и одновременно похвалу жизненной находчивости людей, чинящих одежду (Za tatami są pieniądze).

Большинство рассмотренных единиц относится к рецессивному пласту польского языка и отображает прежние реалии, часть же из них употребляется до сих пор, например załatać coś, przypiąć komuś łatkę, znać pana po cholewach, zostać w jednej koszuli. Анализ генетических значений петрифицированных словосочетаний, известных и неизвестных в современности, позволяет вспомнить о них и найти закрепившиеся в них убеждения 
и суждения, чаще всего исходящие из материального неблагополучия и вытекающего из нее экономного образа жизни человека.

\section{THE IMAGE OF POVERTY ILLUSTRATED IN PHRASEOLOGICAL UNITS AND PROVERBS CONTAINING NAMES OF CLOTHING}

SUMMARY This paper belongs to the cycle of works dedicated to various ways of reflecting the notion of POVERTY in language. Research material comprises multi-word units excerpted from phraseo- and paremiographic collections, which contain components that are names of various items of clothing and activities connected with their production and use. Collected units, in accordance with the assumptions of cultural linguistics, have been analysed in terms of fixed elements of the linguistic image of the world: old realities, as well as social convictions and judgements.

The phraseological units and proverbs discussed illustrate the evaluation the assessment of one's material and social status on the basis of clothing. Inadequate clothing is treated as a symptom of hardship and poverty. At the same time, multiverbisms preserved the image of different activities, which resulted from caring about the state of clothes, and also contain a praise of resourcefulness in this respect.

A lot of the units, which reflect old realities, belong to the recessive level of the Polish language. However, some of them are used in contemporary language, but their genetic meaning is not always clear. The analysis of fixed word combinations makes it possible to show the preserved convictions and judgements about material deprivation and economical lifestyle connected with it.

\section{OBRAZ UBÓSTWA ODZWIERCIEDLONY WE FRAZEOLOGIZMACH I PRZYSŁOWIACH ZAWIERAJĄCYCH NAZWY ODZIEŻY}

STRESZCZENIE Artykuł wpisuje się w cykl prac poświęconych różnym sposobom odzwierciedlenia w języku pojęcia BIEDY. Materiał badawczy stanowią jednostki wielowyrazowe ekscerpowane ze zbiorów frazeo- i paremiograficz-nych, które zawierają komponenty będące nazwami różnych części ubioru lub czynności związanych z ich wyrobem i użytkowaniem. Zebrane jednostki, zgodnie z założeniami lingwistyki kulturowej, zostały zanalizowane pod względem utrwalonych w nich składników językowego obrazu świata: dawnych realiów oraz społecznych przekonań i sądów.

Analizowane frazeologizmy i przysłowia ilustrują wyraziste wartościowanie - ocenę czyjegoś statusu materialnego i społecznego na podstawie ubioru. Niedostatki odzieży i widoczne w niej ubytki traktowane są jako symptomy trudnego położenia, biedy. Jednocześnie multiwerbizmy utrwaliły obraz różnych działań, które wynikały z dbałości o stan odzieży, zawierają także pochwałę życiowej zaradności w tym względzie. 
Wiele poddanych oglądowi jednostek odzwierciedla dawne realia, należy do recesywnej warstwy polszczyzny, część z nich jednak funkcjonuje współcześnie, ale ich znaczenie genetyczne nie zawsze jest znane. Analiza spetryfikowanych połączeń słownych pozwala ukazać utrwalone w nich przekonania i sądy, m.in. na sytuację materialnego niedostatku oraz związanego z nim oszczędnego trybu życia.

\section{ЛИТЕРАТУРА}

I Balowski M., 2019, Petersburskie badania nad przysłowiami czeskimi, „Bohemistyka”, nr 1, s. $125-128$.

I Bartmiński J., 2006, Językowe podstawy obrazu świata, Lublin.

I Chlebda W., 1993, Frazematyka, Encyklopedia kultury polskiej XX wieku, t. II Wspótczesny język polski, red. J. Bartmiński, Wrocław, s. 327-334.

I Krzyżanowski J., 1960, Mądrej głowie dość dwie słowie, t. II: Dwie nowe centurie przystów polskich, Warszawa.

I Malec M., 1998, Etnonimy. Nazwy narodowości. Nazwy mieszkańców, Polskie nazwy własne. Encyklopedia, red. E. Rzetelska-Feleszko, Warszawa-Kraków, s. 180-188.

I Marmuszewski S., 1998, Bogactwo i ubóstwo - dwa motywy potocznego myślenia, „Kultura i Społeczeństwo", 2, s. 119-132.

I Marmuszewski S., 2003, Potoczna percepcja biedy i bogactwa a rozwój kapitalizmu, Bieda i bogactwo w polskiej kulturze i świadomości, red. G. Skąpska, Kraków, s. 95-129.

I Młynarczyk E., 2012, Znać pana po cholewach, czyli utrwalony w przysłowiach obraz ubioru jako symbolu hierarchii społecznej, „LingVaria”, 14, s. 55-64.

I Młynarczyk E., 2015a, Językowo-kulturowy obraz łyka w świetle dawnych frazeologizmów i przysłów, „Annales Universitatis Paedagogicae Cracoviensis. Studia Linguistica” X, s. 120-129.

I Młynarczyk E., 2015b, Językowo-kulturowy obraz biedy w polszczyźnie, „Etnolingwistyka. Problemy Języka $i$ Kultury", 28, s. 147-165.

I Młynarczyk E., 2015c, Sposoby wyrażenia niedostatku materialnego w polskiej leksyce i frazeologii, „Journal of Slavic Languages”, nr 2, s. 57-68.

I Młynarczyk E., 2016a, Językowy obraz pożywienia ludności wiejskiej w sytuacjach niedostatku materialnego (na przykładzie wybranych frazemów), Słowiańska frazeologia gwarowa, red. K. Sikora, M. Rak, Kraków, s. 253-266.

I Młynarczyk E., 2020, Frazemy obrazujące sposób prowadzenia gospodarstwa domowego (rekonesans), Słowiańska frazeologia gwarowa II, red. M. Rak, V. Mokijenko, Kraków, 165-172.

I Olszewski A., 1984, Atlas historycznych i wspótczesnych form obuwia, t. I, Radom.

I Pajdzińska A. 2006, Frazeologia a zmiany kulturowe, Studia frazeologiczne, Łask.

I Rak M., 2015, Bieda, Kulturemy podhalańskie, Kraków, s 239-250.

I Skuza Z. A., 2006, Ginace zawody w Polsce, Warszawa.

I Skąpska G. (red.), 2003, Bieda i bogactwo w polskiej kulturze i świadomości, Kraków.

I Sztetyłła J. (red.), 1992, Nędza i dostatek na ziemiach polskich od średniowiecza po XX w., Warszawa.

I Tarkowska E. (red.), 2000, Zrozumieć biednego. O dawnej i obecnej biedzie w Polsce, Warszawa.

I Wojciechowska A., 2012, Językowy obraz biedy we frazeologii polskiej i francuskiej, „Roczniki Humanistyczne”, LX, z. 8, s. 31-45. 


\section{Словари:}

I NKP - Nowa ksiega przysłów i wyrażeń przysłowiowych polskich, red. J. Krzyżanowski (t. I-III), S. Świrko (t. IV), Warszawa, 1969-1978.

I SFJP - Stownik frazeologiczny języka polskiego, t. I i II, S. Skorupka, Warszawa, 1987.

I SFzP - A. Kłosińska - E. Sobol - A. Stankiewicz, Wielki stownik frazeologiczny PWN z przysłowiami, Warszawa, 2005.

I SJPD-Słownik języka polskiego, t. I-XI, red. W. Doroszewski, Warszawa, 1958-1969. online: http://doroszewski.pwn.pl/.

I SWJP - Słownik wspótczesnego języka polskiego, red. B. Dunaj, Warszawa, 1996.

I WSJP - Wielki słownikjęzyka polskiego, red. P. Żmigrodzki, Kraków. online: wsjp.pl. 